Chirurgia (2021) 116: 361-367

No. 3, May-June

Copyright@ Celsius

http://dx.doi.org/10.21614/chirurgia.116.3.361

\title{
Fibrosis Associated with Retroperitoneal Abscess after Multimodal Treatment of Cervical Carcinoma - A Case Report and Brief Review of the Literature
}

\author{
Alexandru Florin Săvulescu' ${ }^{1 *}$, Cristian Cîrlan', Anca Angela Simionescu², Andreea lulia Budrugeac', \\ Alexandra Bianca Ionescu', Dragoș Stanciu', Florin Cristian Blăjuț' \\ 'Departement of General Surgery, "Dr. Carol Davila" Central Military Emergency University Hospital, Bucharest, Romania \\ 2Department of Obstetrics and Gynecology, "Carol Davila" University of Medicine and Pharmacy, Filantropia Hospital, Bucharest, Romania
}

*Corresponding author:

Alexandru-Florin Săvulescu, MD

"Dr. Carol Davila" Central Military

Emergency University Hospital

134 Plevnei Street, Bucharest, Romania

E-mail: savf|@yahoo.com
Received: 05.09.2020

Accepted: 10.11 .2020

\section{Rezumat}

Fibroză asociată cu abces retroperitoneal după tratamentul multimodal al carcinomului cervical - raportarea unui caz și scurtă revizuire a literaturii

Tratamentul multimodal al cancerului de col uterin cuprinde histerectomia radicală asociată cu limfadenectomia, radioterapia pelvină şi chimioterapia. Fibroza postinflamatorie şi postcancer, asociată cu sindromul de fibroză post radioterapie (RFS) şi limfedemul pot fi cauza unor complicații severe şi a alterării calității vieții.

Cazul clinic : Prezentăm cazul unei paciente de 40 ani, după 7 luni de la terminarea tratamentului standard pentru carcinom scuamos epitelial de col uterin stadiul IIA1 FIGO, care, datorită fibrozei abdominale şi retroperitoneale importante manifestate prin simptomatologie digestivă, a prezentat o alterare a calității vieții după tratament. O colecție abdominală simptomatică şi un abces retroperitoneal au fost tratate în departamentul de chirurgie prin drenaj percutanat şi multiple laparotomii exploratorii de mai multe ori, pe durata unui an. S-au identificat obstrucție intestinală, tumoră pelvică abcedată, fistulă colo-cutanata şi colo-colică stîngă, aderențe intraabdominale şi ureterohidronefroza stângă. Evoluția postoperatorie a fost nefavorabilă cu hemoragie digestive superioară, probabil prin fistula entero-mezenterică cu decesul pacientei.

Concluzie: fibroza poate contribui la evoluția clinică nefavorabilă, cu complicații multiple şi management dificil. Tratamentul chirurgical este îngreunat de fibroza intra şi retroperitoneala, fibroza postneoplazie, şi cea post enteropatie radică, asociată cu 
boală inflamatorie pelvină. Diagnosticul de abces retroperitoneal poate fi dificil, datorită simptomatologiei nespecifice.

Cuvinte cheie: fibroză, cancer col uterin, radioterapie, complicații gastro-intestinale, enteropatia de iradiere, sindromul de fibroza radică

\begin{abstract}
Background: The multimodal treatment options for cervical carcinoma are represented by either radical hysterectomy associated with pelvic lymph node dissection, pelvic radiation therapy or chemotherapy. Inflammatory and post-neoplasia fibrosis associated with post-radiation fibrosis syndrome (RFS) and lymphedema may cause severe complications and quality of life alteration.

Case report: Here we present a case of a 40-year-old woman, seven months after completing standard treatment for squamous cervical cancer FIGO IIA1 with a negative impact on the quality of life due to an important abdominal and retroperitoneal fibrosis leading to significant gastrointestinal symptoms. Over a year, a symptomatic intraabdominal collection and a retroperitoneal abscess were managed in the surgery department by percutaneous drainage and exploratory laparotomy. Bowel obstruction, abscessed pelvic tumor, left colocutaneous and colocolic fistula, intra-abdominal adhesions and left uretero-hydronephrosis were found. Postoperatively, the evolution was unfavorable with upper gastrointestinal bleeding probably due to entero-mesenteric fistula followed by death.

Conclusion: Fibrosis can contribute to unfavorable clinical evolution with multiple complications and difficult management. Intra- and retroperitoneal fibrosis, neoplasia and post radiation enteropathy associated with pelvic inflammatory disease make the surgical approach difficult. Diagnosis of retroperitoneal abscess may be challenging due to nonspecific symptoms.
\end{abstract}

Key words: fibrosis, cervical carcinoma, radiation therapy, gastrointestinal complications, radiation enteropathy, radiation fibrosis syndrome

\section{Introduction}

Cervical carcinoma is the second leading cause of morbidity and mortality of women in Romania and an important morbidity related cancer in the world. In 2018, Romania reported 3308 new cases of cervical cancer which represented $8.6 \%$ of all types of cancer (1).

The multimodal recommended treatment in FIGO IIA stage of cervical cancer is either radiation therapy or radical surgical intervention with or without associated radiation therapy (RT) combined with chemotherapy (2). Brachytherapy will be followed approximately 1-2 weeks after the end of external radiation therapy. It is an essential component of treatment for locally advanced cervical cancer and allows for a higher dose of RT to the cervix while sparing the surrounding normal tissue. Modern technology allows the therapeutic ratio to be optimized minimizing the dose to surrounding tissues and maximizing the dose applied to the target tissue, while also dividing the total dose of radiation into smaller daily doses, thus trying to avoid major side-effects of radiation (intensitymodulated radiotherapy optimization) (3). However, radiation therapy administered in the pelvic area usually causes some immediate side effects like gastrointestinal motility disorders (GI), dysuria, and vaginal bleeding, as well as long-term effects such as fibrosis in all tissues and lymphedema. Late stage symptoms that affect different systems 
(gastrointestinal tract, genitourinary tract, derma and the osteomuscular system) like enteritis, proctitis, enteral fistula, strictures, obstructions in the gastrointestinal tract, cystitis, vaginal stenosis, skin ulcerations, osteopenia, avascular necrosis are reported. Chronic enteropathy usually occurs 3 months or more after radiation therapy and is characterized by mucosal atrophy, vascular sclerosis, and progressive fibrosis of the intestinal wall. The symptoms are chronic and progressive and are characterized by malabsorption of nutrients and gastrointestinal motility disorders (4-6). The quality of life can be affected by these complications, sometimes requiring additional investigations, surgical reinterventions and palliative treatment. The Multinational Association of Supportive Care in Cancer (MASCC) has published strategies to minimize the effects of radiation based on literature review (7).

We report a case of unfavorable outcome due to side effects of radiotherapy seven months after management of cervical cancer. Fibrosis and severe gastrointestinal symptoms affect quality of life and causemultiple surgical interventions and death.

\section{Case Report}

A 40-year-old woman is admitted to the emergency department for diffuse abdominal pain over the previous 24 hours. She was treated seven months before for FIGO stage IIA 1 of keratinizing squamous cell carcinoma undergoing neoadjuvant radiation therapy (RT) along with chemotherapy followed by radical surgery. Neoadjuvant $3 \mathrm{D}$ conformal radiation therapy was performed at the level of a pelvic target volume of DT=50Gy/25fr, together with chemotherapy (cisplatin 40 $\mathrm{mg} / \mathrm{m}^{2}$ weekly during RT) followed by endocavitary HDR brachytherapy at the uterovaginal level $\mathrm{DT}=15 \mathrm{~Gy} / 2 \mathrm{fr}$. After the radiation therapy, the patient presented cervical bleeding and severe anemia and had undergone radical surgical treatment (Wertheim Meigs operation type III) with a favorable postoperative evolution.

In the emergency unit, clinical and laboratory tests show fever $\left(38^{\circ} \mathrm{C}\right)$ and hyperleukocytosis; the CT scan reveals intra-abdominal collections corresponding to the left flank (Fig. $1 \mathrm{~A}$ ) and left iliac fossa, fibrosis and left ureterohydronephrosis. An ultrasound guided percutaneous drainage of the intra-abdominal collections was performed. The intra-abdominal collections were filled with a serous fluid of citrine color. The improvement in the general condition, permanent afebrile, minimal drainage are favorable and allow the patient to be discharged from hospital. Fig. $1 B$ shows the correct position of the percutaneous drain left in place.
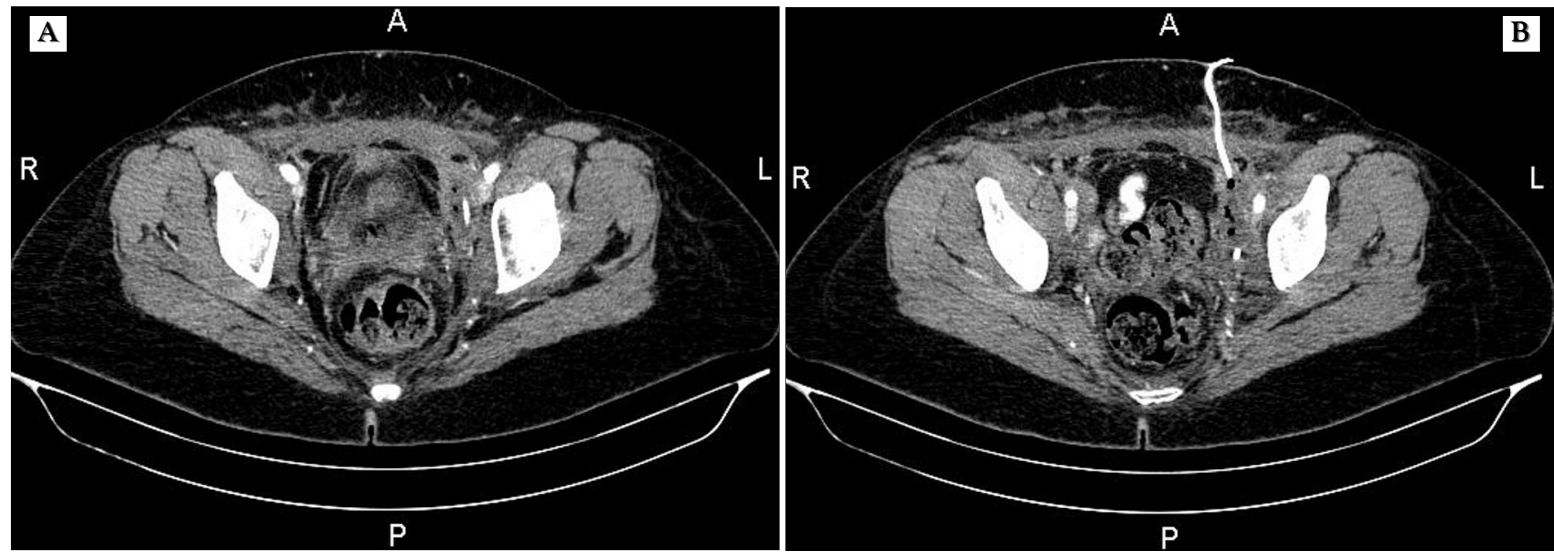

Figure 1. (A) Axial CT imag : left retroperitoneal collection, with mixed water and air content that extends to the ilio-psoas muscle and to the left external iliac artery and retro parietal pelvis, with fibrosis of the left anterior pelvic wall. (B) Axial CT images: Percutaneous drainage of left retroperitoneal abscess with infiltration of the left anterior pelvic wall. 
Two months later, the patient complained again of pain in the right flank, fever, shivers, dysuria, and gastrointestinal motility disorders. The native CT scan (chest, abdomen, pelvis) along with the clinical examination diagnosed a retroperitoneal abscess. Exploratory laparoscopy was performed and severe pelvic and left parieto-colic adhesions with the appearance of enteral fibrosis were diagnosed (Fig. 2 A, B). Adhesiolysis was difficult, classifying the adhesion syndrome as Hobson stage V. The appearance of the tissues was modified, making it difficult to visualize the anatomical elements. Surgical drainage of the retroperitoneal abscess was performed. A post-operative lymphedema in the left limb after exclusion of a deep vein thrombosis had occurred.

The patient is discharged five days postoperatively, with favorable evolution, but is readmitted one month later for pain in the left flank and hypogastrium, altered general status, fever, and gastrointestinal motility disorder. Clinical and imaging exams (CT examination of the abdomen and pelvis) established the diagnosis of parietal abscess of the left iliac fossa and retroperitoneal abscess (compared with the previous examination, an evolution of the retroperitoneal collection can be observed). A percutaneous incision of the parietal abscess at the level of the left iliac fossa with evacuation of gas and purulent liquid was done. After multidisciplinary decision, an expectative follow-up with complete blood count, renal and hepatic function monitoring was decided for the retroperitoneal collection. The regulation of hydroelectrolytic balance and hemodynamics was associated with antibiotics (Metronidazole $500 \mathrm{mg} / 100 \mathrm{ml}$ intravenous infusion every 8 hours plus Meropenem iv $1000 \mathrm{mg}$ every 12 hours), antiinflammatory, analgesic, antisecretory, antispastic, prokinetic, and low molecular weight heparin for preventing deep vein thrombosis. Due to the persistence of the abdominal pain and the left iliac mass associated with fever and absence of gastrointestinal motility a new drainage of the abscess containing fecaloid fluid was performed. A new laparotomy was performed due to the unfavorable postoperative evolution with fever and persistence of absence of gastrointestinal motility symptoms. Intraoperatively, bowel obstruction and abscessed pelvic tumor, colocutaneous fistula in the left flank area, colocolic fistula, left ureterohydronephrosis, and severe adhesion syndrome are noted (Fig. $2 A$ and $2 \mathrm{~B}$ ). We performed extensive enterectomy with ileostomy, sigmoid colectomy with colostomy, evacuation of psoas abscess, peritoneal lavage,
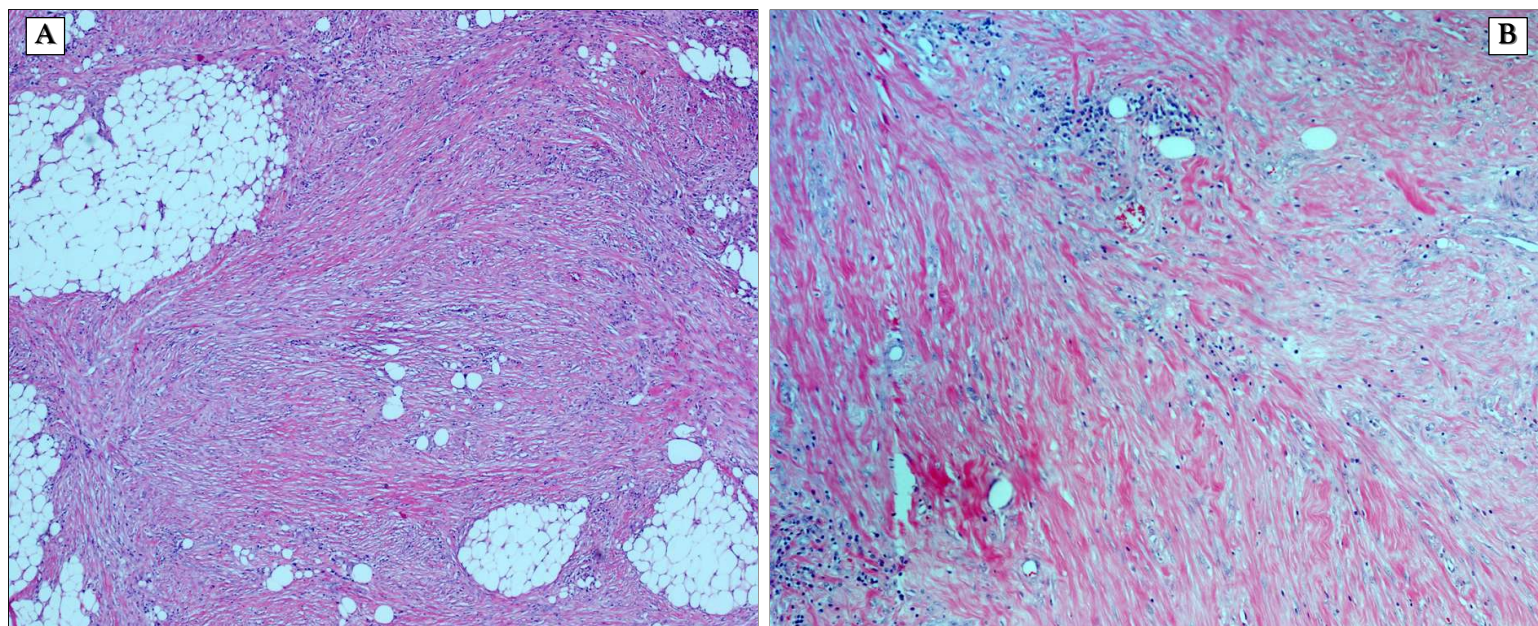

Figure 2. (A) Histopathology of the large intestinal wall: post radiation lesions - fibrosis with moderate polymorphic inflammatory infiltrate affecting the adipose tissue of the subserosa. Sections of HE-staining: Magnification x 25. (B) Histopathology of the large intestinal wall: post radiation lesions - extensive fibrosis with polymorphic inflammatory process and neoformation vessels. Sections of HE-staining: Magnification x 100. 
multiple drainage, dual-mesh and reinforcement, polypropylene mesh of the anterior abdominal wall.

The immediate postoperative recoverywas slowly favorable; the worsening of the lymphedema in the lower left limb occurred, also the development of a dehiscence at the lower pole of the mid abdominal wound, treated with active aspiration drainage for 6 days. The patient is discharged two weeks postoperatively, with an improved general status, and to continue wound care treatment.

Two weeks later, the patient presents increased fatigability and externalization of blood and clots at the ileostomy level. Hospitalization is decided for further investigation and treatment. Hydroelectrolytic and acid-base balance is established along with prophylaxis of stress ulcer and deep vein thrombosis. Digestive endoscopy does not detect pathological modifications up to the level of the duodenum II. Two days later, the patient presents massive hematemesis with hemodynamic instability and she was admitted to the Intensive Care Unit. High dose vasopressor treatment is established along with hydroelectrolytic and acid-base rebalancing treatment. Blood products are administered. The patient's condition worsens under maximal treatment. Emergency upper digestive endoscopy is performed for diagnostic purposes. It detects large amounts of blood and clots in the stomach. When passing from the duodenal bulb to the second duodenum, a voluminous clot is detected that does not allow the passage of the endoscope. After the procedure, the patient is under cardiac arrest by pulse-free ventricular tachycardia, and was resuscitated for 2 minutes. Orotracheal intubation is decided, the vasopressor treatment is maintained in maximum doses and surgery is decided for hemorrhagic shock with upper digestive hemorrhage of uncertain etiology. Exploratory laparotomy reveals distended stomach and jejunal loops, mesenteric inflammatory block, and intense perivisceritis. Gastrotomy and wide duodenotomy is performed with aspiration of blood and clots. The duodeno-jejunal flexure is taken off, with blood externalization from the distal level, jejuno-ileal take-off is attempted, but it turned out to be impossible due to the inflammatory process. A superior mesenteric fistula was diagnosed, unmanageable due to the mesenteric aeropathic fibrosis. Exitus on day 1 postoperative was reported. All pathology reports confirm tissular fibrosis with inflammatory cells without malignancy.

This report follows the ethical norms of scientific research and the principles of anonymity and confidentiality for case reports approved by the local Ethical Committee. The patient acknowledged and signed the Informed Consent for the treatment and for using this case for educational and scientific research purposes.

\section{Discussions}

Intra- and retroperitoneal fibrosis make surgical management difficult. Retroperitoneal fibrosis may result from the local spread of infection from inflammatory pelvic disease, secondary to malignancy or post radiation $(8,9)$. Post radiotherapy hypoxia may induce the activation of the tumor microenvironment, modulating immune reaction, and promoting inflammation and fibrosis (10). CT is useful for differentiating malignant from non-malignant fibrosis using the signal intensity (11) as is retroperitoneal soft tissue. It is well-known that radiation may produce local injury of tissue and fibrosis 4-12 months after radiation therapy (12), chronic radiation enteropathy remains an important issue due to the long term effects of pelvic radiotherapy (13). Diagnosis of retroperitoneal abscess can be difficult mainly due to nonspecific symptoms (14). The treatment of choice is radiologically guided percutaneous drainage, although there is still some controversy over the superiority of surgical drainage. Modern interventional technology makes percutaneous drainage a safe and a feasible intervention $(14,15)$. For the reported case, an ultrasound-guided percutaneous drainage was initially chosen and maintained for three months. Although the collections initially decreased in size, they did not recover 
completely, later highlighting their evolution. However, the surgical drainage was difficult due to the fibrosis and intense adhesion syndrome and radiation enteropathy.

In this case, the fibrotic retroperitoneal appearance and the intense enteral adhesion process were detected intraoperatively approximately 7 months after radiotherapy. The reported incidence of post-radiotherapy gastrointestinal damage is between $8 \%$ and $50 \%$ in the case of radiotherapy for cervical neoplasm (16-19), associated with obstructions, fistulas, perforations or hemorrhage, requiring surgical treatment (20). Retroperitoneal fibrosis associated with radiotherapy and chemotherapy are very rarely reported. Takahashi et al. reported a case of retroperitoneal fibrosis (RPF) following radiotherapy with ureteral compression and uretherohydronephrosis managed successfully by stent placement and corticotherapy (21).

Lower limb lymphedema is mainly due to lymph node dissection and to radical surgery $(22,23)$; post-radiation fibrosis may exacerbate the symptomatology (24).

The patient returned several times to the emergency unit, required multiple surgeries with complications due to fibrosis. Tissue fibrosis and chronic enteritis determine extensive adhesiolysis and difficult surgery. In this case, the complications found were: retroperitoneal collections, colocolonic fistula, colocutaneous fistula, and possibly enteromesenteric fistula. All the surgical interventions were difficult and although the immediate postoperative response was favorable, the long-term status of the patient worsened.

\section{Conclusion}

In conclusion, when treating patients with cervical cancer, the multidisciplinary team and the surgeon must be aware of dealing with complex fibrosis due to cancer (fibroblasts), to pelvic inflammatory disease, and post-radio and chemotherapy.

\section{Conflicts of Interest and Source of Funding}

The authors report no conflict of the interest.
No funding was received for this manuscript.

\section{Ethics Approval}

The study was conducted according to the guidelines of the Declaration of Helsinki Ethical review and approval was waived for this study, due to the type of the article "case report and literature review".

\section{References}

1. http://gco.iarc.fr/today/data/factsheets/populations/642-romania-factsheets.pdf accessed on August 2020

2. Cervical cancer guidelines ESGO 2018 available at https://guidelines.esgo. org/media/2018/04/Cervical-cancer-Guidelines-Complete-report.pdf accessed on August 2020

3. Viswanathan AN, Lee LJ, Eswara JR, Horowitz NS, Konstantinopoulos PA, Mirabeau-Beale $\mathrm{KL}$, et al. Complications of pelvic radiation in patients treated for gynecologic malignancies. Cancer. 2014;120(24):3870-83.

4. Yang J, Ding C, Zhang T, Zhang L, Lv T, Ge X, et al. Clinical features, outcome and risk factors in cervical cancer patients after surgery for chronic radiation enteropathy. Radiat Oncol. 2015;10:128

5. Viswanathan AN, Lee LJ, Jairam R, Eswara JR, Horowitz NS, Panagiotis A, et al. Complications of pelvic radiation in patients treated for gynecologic malignancies. Cancer. 2014;24:3870-3883.

6. Hauer-Jensen M, Denham JW, Andreyev HJ. Radiation enteropathypathogenesis, treatment and prevention. Nat Rev Gastroenterol Hepatol. 2014;11(8):470-479.

7. Gibson RJ, Keefe DMK, Lalla RV, Bateman E, Blijlevens N, Fijlstra M, et al. Systematic review of agents for the management of gastrointestinal mucositis in cancer patients. Support Care Cancer. 2013;21(1):313-26.

8. Vaglio A, Salvarani C, Buzio C. Retroperitoneal fibrosis. Lancet. 2006; 367(9506):241-251.

9. Piersma B, Hayward MK, Weaver VM. Fibrosis and cancer: A strained relationship. Biochim Biophys Acta Rev Cancer. 2020;1873(2):188356.

10. Wang Z, Tang Y, Tan Y, Wei Q, Yu W. Cancer-associated fibroblasts in radiotherapy: challenges and new opportunities. Cell Commun Signal. 2019:17(1):47

11. Bakir B, YImaz F, Turkay R, Ozel S, Bilgic B, Velioglu A, et al. Role of diffusion-weighted MR imaging in the differentiation of benign retroperitoneal fibrosis from malignant neoplasm: Preliminary Study. Radiology. 2014; 272(2):438-45

12. Straub JM, New J, Hamilton CD, Lominska C, Shnayder Y, Thomas SM. Radiation-induced fibrosis: mechanisms and implications for therapy. J Cancer Res Clin Oncol. 2015;141(11):1985-94

13. Denham JW, Hauer-Jensen M. Radiation induced bowel injury: a neglected problem. Lancet. 2013;382(9910):2046-2047.

14. Lobo DN, Dunn WK, Iftikhar SY, Scholefield JH. Psoas abscesses complicating colonic disease: imaging and therapy. Ann R Coll Surg Engl. 1998; 80(6):405-409

15. Dinç H, Ahmetoglu A, Baykal S, Sari A, Sayil O, Gümele HR. Image-guided percutaneous drainage of tuberculous iliopsoas and spondylodiskitic abscesses: midterm results. Radiology. 2002;225(2):353-358.

16. Rijkmans EC, Nout RA, Rutten IH, Ketelaars M, Neelis KJ, Laman MS, et al. Improved survival of patients with cervical cancer treated with imageguided brachytherapy compared with conventional brachytherapy. Gynecol Oncol. 2014:135(2):231-238

17. Kuku S, Fragkos C, McCormack M, Forbes A. Radiation-induced bowel injury: the impact of radiotherapy on survivorship after treatment for 
gynaecological cancers. Br J Cancer. 2013;109(6):1504-12.

18. Mabuchi S, Okazawa M, Isohashi F, Matsuo K, Ohta Y, Suzuki O, et al. Radical hysterectomy with adjuvant radiotherapy versus definitive radiotherapy alone for FIGO stage IIB cervical cancer. Gynecol Oncol. 2011; 123(2):241-247.

19. Abayomi JC, Kirwan J, Hackett AF. Coping mechanisms used by women in an attempt to avoid symptoms of chronic radiation enteritis. J Hum Nutr Diet. 2009;22(4):310-316.

20. Andreyev J. Gastrointestinal complications of pelvic radiotherapy: are they of any importance? Gut. 2005;54(8):1051-1054.

21. Takahashi $Y$, Matsushima H, MoriT, Kokabu T, Ito F, Kitawaki J.
Retroperitoneal fibrosis after chemo-radiotherapy for cervical cancer: A case report. J Obstet Gynecol Research. 2019;4:938-941.

22. Biglia N, Zanfagnin V, Daniele A, Robba E, Bounous VE. Lower Body Lymphedema in Patients with Gynecologic Cancer. Anticancer Res. 2017; 37(8):4005-4015.

23. Hobson KG, DeWing M, Ho HS, Wolfe BM, Cho K, Greenhalg. Expression of transforming growth factor beta1 in patients with and without previous abdominal surgery. DG Arch Surg. 2003;138(11):1249-1252.

24. Achouri A, Huchon C, Bats AS, Bensaid C, Nos C, Lécuru F. Complications of lymphadenectomy for gynecologic cancer. Eur J Surg Oncol. 2013; 39(1):81-86. 